\title{
Kajian Sistem Pengolahan Minyak Kelapa Murni (Virgin Coconut Oil) dengan Metode Pemanasan
}

\section{Teuku Zulfadli*}

\section{A R T I C L E I N F O Article history: Received 20 November 2017 \\ Received in revised form 15 Desember 2017 Accepted 16 Januari 2018 Available online 25 Februari 2018

\begin{tabular}{l}
\hline Kata Kunci: \\
Sistem Pengolahan, \\
Minyak Kelapa Murni \\
(Virgin Coconut Oil), \\
Metode Pemanasan
\end{tabular}

Keywords:

Processing system, The pure coconut oil, (virgin coconut oil). Heating method

\begin{abstract}
A B S T R A K
Minyak kelapa murni atau Virgin coconut oil merupakan modifikasi dari pembuatan minyak kelapa sehingga menghasilkan produk dengan kadar air dan kadar asam yang lebih rendah, berwarna bening dan mempunyai daya simpan yang cukup lama yaitu 12 bulan. Dari segi ekonomi minyak kelapa murni mempunyai harga jual yang lebih tinggi dibanding minyak kelapa yang diolah secara tradisional dengan memanaskan santan atau mengendapkan santan dalam waktu yang lama sehingga menghasilkan bau tengik dan kualitas yang kurang baik akibat kadar air dan asam lemak bebas yang masih tinggi. Tujuan penelitian ini adalah untuk mendapatkan minyak kelapa murni dengan kadar air dan asam lemak bebas yang lebih rendahsesuai SNI. Ada 3 metode pembuatan minyak kelapa murni yakni metode fermentasi, pancingan dan pemanasan, adapun metode yang digunakan dalam penelitian ini adalah metode pemanasan, metode pemanasan yang diuji dengan pemanasan bertahap maupun sekali pemanasan, untuk pemanasan bertahap dilakukan pemanasan awal dengan temperatur $60-110^{\circ} \mathrm{C}$ dengan 9 jam waktu pengeringan dan pemanasan akhir dengan variasi temperatur $60^{\circ} \mathrm{C}$ (sampel A), $70^{\circ} \mathrm{C}$ (sampel B), $80^{\circ}$ (sampel C) dan waktu pengeringan 5 jam, 4 jam dan 3 jam. Hasil penelitian menunjukan bahwa temperatur udara pengering berpengaruh pada kualitas produk dan lamanya waktu pengeringan. Hasil perhitungan dan pengujian menunjukan pengolahan yang paling efektif yaitu pada sampel $\mathrm{A}$ dengan kadar air dan kadar asam lemak bebas yang paling rendah mencapai $0,08 \%$ dan $0,10 \%$
\end{abstract}

A B S T R A C T

Pure coconut oil or Virgin coconut oil is a modification of making coconut oil to produce products with the lower water and acid level, clear and has a long shelf life of 12 months. In terms of economics, pure coconut oil has higher selling price compared to traditional coconut oil by heating coconut milk or precipitating coconut milk in a long time so as to produce rancid odor and poor quality due to high water content and free fatty acid. The purpose of this study was to obtain pure coconut oil with lower water content and free fatty acids according to SNI. There are 3 methods of making pure coconut oil that is method of fermentation, induction and heating, while the method was used in this research is the method of heating. Heating method which is tested by gradual heating or once heating, for gradual warming done preheat with temperature 60-110 ${ }^{\circ} \mathrm{C}$ with 9 hours of drying and heating time with $60^{\circ} \mathrm{C}$ temperature variations (sample A), $70^{\circ} \mathrm{C}$ (sample B), $80^{\circ}$ (sample $\mathrm{C}$ ) and 5 hours, 4 hour and 3 hour drying time. The results showed that drying air temperature had an effect on product quality and length of drying time. The results of the calculation and testing showed the most effective treatment that is on the sample $A$ with water content and free fatty acid content of the lowest reached $0.08 \%$ and $0.10 \%$. 


\section{Pendahuluan}

Provinsi Aceh secara topografi merupakan daerah yang memiliki potensi pengembangan kelapa yang cukup besar. Luas area tanaman kelapa diProvinsi Aceh mencapai 102.671 Ha dengan hasil produksi sekitar 59.000 ton/tahun. (Dinas Perkebunan, 2012)

Pada umumnya petani kelapa menjual kelapa dalam keadaan basah di pasaran lokal. Pada saat panen raya, produksi kelapa melebihi kebutuhan lokal, sehingga banyak kelapa yang tidak termanfaatkan, yang menyebabkan harga kelapa menurun drastis. Hal ini tentu sangat merugikan petani kelapa, sehingga untuk meningkatkan taraf hidup dan ekonomi para petani pada pasca panen diperlukan penambahan produk pengolahan buah kelapa, salah satu produk pengolahan buah kelapa adalah sebagai bahan baku pembuatan minyak kelapa.

Salah satu minyak kelapa yang didapat dari pengolahan produk kelapa adalah minyak kelapa murni atau yang biasa disebut Virgin Coconut Oil (VCO). Dari segi ekonomi minyak kelapa murni mempunyai harga jual yang lebih tinggi dibanding minyak kelapa biasa yang diolah secara tradisional dengan memanaskan santan atau mengendapkan santan dalam waktu yang lama sehingga menghasilkan bau yang tengik akibat kadar air yang masih tinggi. Minyak kelapa murni atau VCO merupakan modifikasi proses pembuatan minyak kelapa sehingga dihasilkan produk dengan kadar air dan kadar asam lemak bebas yang lebih rendah, berwarna bening, berbau harum serta mempunyai daya simpan yang cukup lama yaitu 12 bulan. (Ketaren, 1986)

Ada beberapa metode pembuatan VCO yang dapat digunakan diantaranya adalah pemanasan, fermentasi dan pemancingan. Pengolahan metode pembuatan VCO dengan metode pemanasan, merupakan metode pengolahan minyak kelapa murni yang memungkinkan diaplikasikan pada berbagai skala industri atau usaha dikarenakan lebih ekonomis dan praktis, dengan melakukan penyesuaian ukuran dan jenis peralatan serta sistem kendali proses. (Ketaren, 1986)

Maka dari itu penelitian ini menguji proses pengolahan VCO dengan sistem pemanasan yang direncanakan menggunakan oven sebagai alat pemanas dalam proses pengolahan minyak kelapa murni atau VCO, mengatur distribusi temperatur secara menyeluruh dan memvariasikan temperatur serta melakukan pengujian untuk mendapatkan rendemen dan hasil produk minyak yang lebih banyak dan memakan waktu lebih sedikit dibanding dengan cara tradisional. Kemudian dilakukan peninjauan terhadap berkurangnya kadar air dari kelapa dan minyak kelapa murni yang dipanaskan sampai memenuhi SNI.

Pengeringanmerupakan suatu metode untuk mengeluarkan atau menghilangkan sebagian air dari suatu bahan dengan cara menguapkan kadar air dari bahan tersebut. biasanya kandungan air bahan dikurangi sampai suatu batas tertentu agar mikroba tidak dapat tumbuh lagi di dalamnya.

Proses Termodinamika proses pengeringan memerlukan energi panas untuk menguapkan kadar air yang ada pada bahan yang dikeringkan untuk kasus pengeringan kelapa, proses Termodinamika meliputi pemberian energi panas pada kelapa yang akan dikeringkan. Kemudian energi panas yang diterima kelapa (objek pengering) tersebut akan memanaskan air yang terkandung dalam daging kelapa, sehingga air akan melepaskan diri dari objek yang dikeringkan sehingga menjadi kelapa kering.

Proses perpindahan panas terjadi karena temperatur bahan lebih rendah daripada temperatur yang dialirkan sekelilingnya. Panas yang diberikan itu akan menaikan temperatur bahan dan menyebabkan tekanan uap air dari bahan ke udara merupakan perpindahan massa sebelum proses pengeringan, tekanan uap air pada bahan berada dalam kesetimbangan dengan tekanan uap air di sekitarnya. ketika proses pengeringan dimulai, udara panas yang dialirkan melalui permukaan bahan akan menaikan tekanan uap air. terutama pada daerah permukaan yang sejalan dengan kenaikan temperaturnya. Pada proses ini terjadi perpindahan massa dari bahan dalam bentuk uap air atau terjadi proses pengeringan pada permukaan bahan.

Energi yang dibutuhkan untuk menaikan temperatur ruang pengering diketahui dengan menggunakan persamaan:

$$
\mathrm{Q}=\mathrm{m} \cdot \mathrm{Cp} \cdot \Delta T \text {... }
$$

Dimana :

$\mathrm{Q}=$ Energi panas $(\mathrm{kJ})$

$\mathrm{m}$ = Massa udara panas didalam ruang pengering $(\mathrm{kg})$

$\mathrm{Cp}=$ Panas spesifik udara $\left(\mathrm{J} / \mathrm{kg}{ }^{\circ} \mathrm{C}\right)$

$\Delta T=$ Perbedaan temperatur udara pengering $\left({ }^{\circ} \mathrm{C}\right)$ 
Sedangkan energi panas yang dibutuhkan untuk proses pengeringan kelapa didapat dengan menggunakan persamaan :

$Q_{\text {pengeringan }}=$ Mn.Lh.

Keterangan :

$\mathrm{Mn}=$ berat kelapa setelah dikeringkan $(\mathrm{kg})$

$\mathrm{Lh}=$ panas laten pada temperatur $(\mathrm{kJ} / \mathrm{kg})$

Kesetimbangan Kadar Air

Untuk menentukan Kadar air suatu bahan dapat dinyatakan dengan rumus dibawah ini (sumber : F.G. winarno ,1993) :

$$
\mathrm{KA}=\frac{W b-w k}{W b} \times 100
$$

Dimana :

$\mathrm{KA}=$ Kadar air berdasarkan bahan basah (wet

basis) ( \%).

$\mathrm{Wb}=$ Berat bahan sebelum pengeringan $(\mathrm{kg})$

$\mathrm{Wk}=$ Berat bahan setelah pengeringan $(\mathrm{kg})$

Kadar air kesetimbangan (equilibrium moisture content) adalah kesetimbangan antara kadar air bahan dengan suhu kelembaban udara sekitarnya. Kesetimbangan ini terjadi pada suhu tertentu dan ditentukan oleh kelembaban relative tertentu. (Taib, et, al, 1988)

\section{Metode}

Peralatan Penelitian

a. Oven Pengering

Peralatan pengering dengan energi pembakaran ini dirancang untuk penelitian dalam skala kecil dan terdiri dari beberapa bagian yang memiliki keterkaitan yang sangat penting untuk keseluruhan proses pengeringan.

Peralatan oven pengering yang digunakan terdiri dari beberapa bagian bagian, yaitu lemari pengering, rak pengering, ruang bakar, sudut pengarah seperti yang diperlihatkan oleh gambar 1 . berikut:

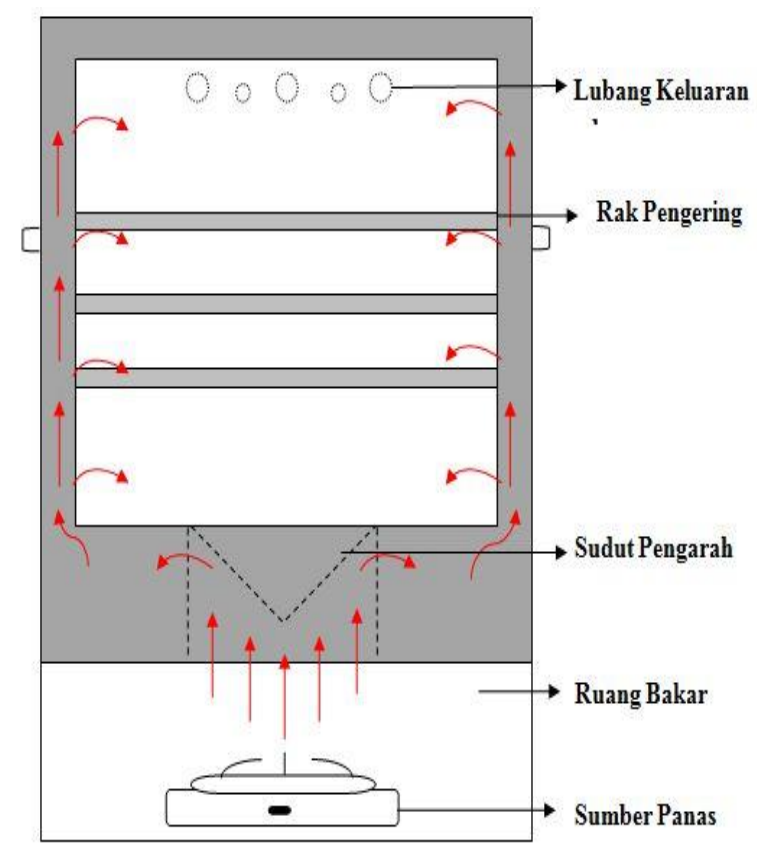

Gambar 1. Mekanisme Aliran Udara ke dalam Ruang Pengering pada Oven Pengering 
b. Alat Pemarut

Alat Pemarut yang digunakan berupa alat pemarut kelapa sederhana yang terdapat pada masyarakat umumnya. Alat pemarut ini berfungsi untuk memarut kelapa yang telah mengalami proses pemanasan awal yaitu pemisahan daging kelapa dan tempurung tujuannya untuk mengurangi kadar air kelapa dengan cepat akibat pengurangan luas permukaan kelapa dan mempermudah proses pengepressan kelapa.

\section{c. Alat Pengepress}

Alat Pengepres yang digunakan merupakan alat pengepres santan dengan menggunakan ulir tanpa hydraulic, Alat pengepres ini berfungsi untuk mengepres kelapa yang sudah mengalami proses pemanasanan awal dan akhir sehingga menghasilkan minyak kelapa yang diinginkan. Alat pengepres dapat dilihat pada Gambar 2 berikut.

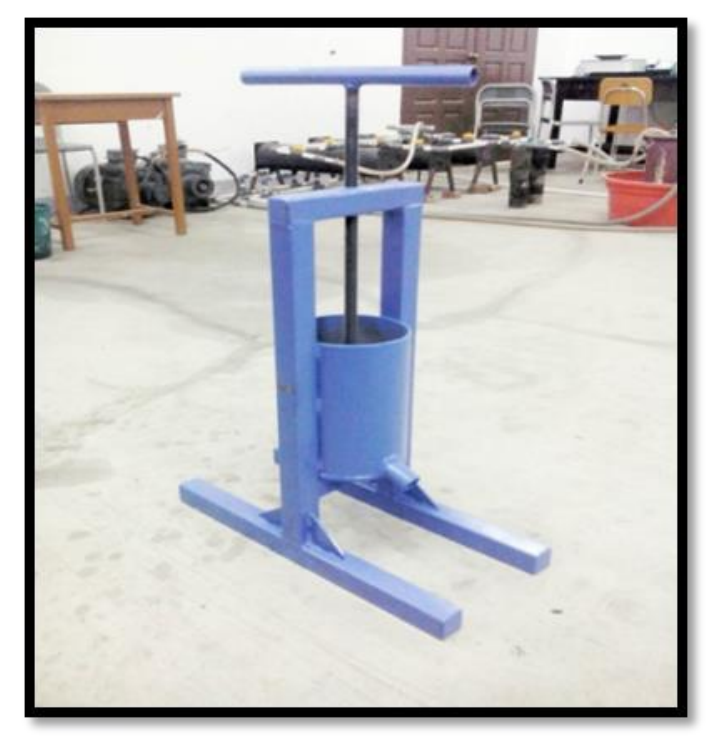

Gambar 2. Alat Pengepress

a. Peralatan Ukur

Peralatan ukur yang digunakan : a) Termometer Digital, b) Stopwatch, c) Timbangan Digital

b. Bahan yang dikeringkan

Bahan yang dikeringkan adalah buah kelapa tua hijau yang segar. Pada penelitian peneliti menggunakan 7 butir kelapa tua yang sudah dibelah beberapa bagian.

\section{c. Tata Cara Pengujian}

Adapun tata cara pengujian yang akan dilaksanakan :1) Menyiapkan sampel kelapa yang dibelah beberapa bagian dan menimbang sampel yang akan digunakan. 2) Kelapa yang sudah ditimbang dimasukan kedalam ruang pengering dengan temperatur $60-110^{\circ} \mathrm{C}$ untuk proses pemanasan awal dengan waktu 9 jam. 3) Setelah kelapa mengalami proses pemanasan awal lembaga putih atau daging kelapa kering yang sudah terpisah dari tempurungnya dilakukan proses pemarutan. 4) Kelapa yang sudah diparut dimasukan kedalam ruang pengering dengan temperatur yang divariasikan yaitu $: 60^{\circ} \mathrm{C}, 70^{\circ} \mathrm{C}$ dan $80^{\circ} \mathrm{C}$ untuk proses pemanasan akhir. 5) Kelapa hasil pemanasan akhir ditimbang beratnya untuk mengetahui jumlah kadar air yang berkurang. 6) Setelah penurunan kadar air didapat, kelapa dipress untuk mendapatkan minyak kelapa murni yang diinginkan. 7) Setelah itu minyak kelapa murni yang dihasilkan di uji kandungan air dan asam lemak bebasnya dibalai pengujian.

\section{Hasil dan Pembahasan}

Pada penenlitian ini diperoleh data-data dari pengujian dengan kondisi temperatur yang divariasikan. Proses pengolahannya dengan pemanasan bertahap maupun sekali pemanasan, yaitu : 1) Sampel A dengan proses pemanasan awal kelapa yaitu pada temperatur $\pm 80-110^{\circ} \mathrm{C}$ dengan waktu pengeringan selama $9 \mathrm{jam}$. Dan temperatur pemanasan akhir $\pm 60^{\circ} \mathrm{C}$ dengan waktu pengeringan selama 5 
jam. 2) Sampel B dengan proses pemanasan awal kelapa yaitu pada temperatur $\pm 80-110^{\circ} \mathrm{C}$ dengan waktu pengeringan selama 9 jam. Dan temperatur pemanasan akhir $\pm 70^{\circ} \mathrm{C}$ dengan waktu pengeringan selama 4 jam. 3) Sampel C dengan proses pemanasan awal kelapa yaitu pada temperatur $\pm 80-110^{\circ} \mathrm{C}$ dengan waktu pengeringan selama 9 jam. Dan temperatur pemanasan akhir $\pm 80^{\circ} \mathrm{C}$ dengan waktu pengeringan selama 3 jam. 4) Sampel D dengan sekali proses pemanasan kelapa yaitu pada temperatur $\pm 60-80^{\circ} \mathrm{C}$ dengan waktu pengeringan selama 10 jam.

Dari penelitian kita dapat mengetehaui laju penurunan massa dan laju penurunan kadar air yang akan diplot kedalam grafik sebagai berikut :

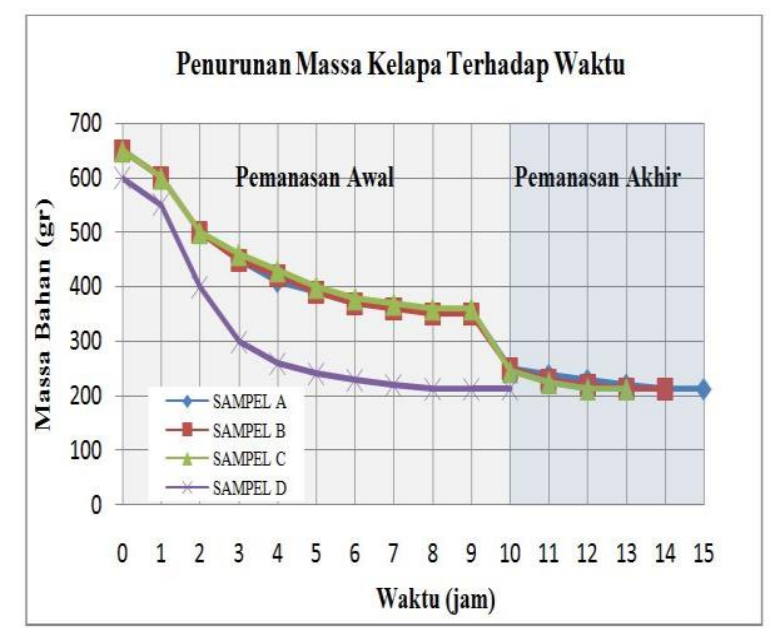

Gambar 3. Grafik perbandingan laju penurunan massa sampel kelapa

Gambar 3. diatas menjelasakan tentang perbandingan massa kelapa terhadap waktu pengeringan sehingga mencapai kadar air maks 0,2 \% (SNI 7381,2008). Massa kelapa Sampel A setelah pengeringan sebesar 212,9 gr dengan temperatur pemanasan awal sebesar $110^{\circ} \mathrm{C}-80^{\circ} \mathrm{C}$ dan waktu pengeringan 9 jam dan juga dengan temperatur pemanasan akhir sebesar $60^{\circ} \mathrm{C}$ dan waktu pengeringan yang dibutuhkan selama 5 jam. Massa kelapa Sampel B setelah pengeringan sebesar 213 gr dengan proses pemanasan awal yang sama dengan sampel A dan juga dengan temperatur pemanasan akhir sebesar $70^{\circ} \mathrm{C}$ dan waktu pengeringan yang dibutuhkan selama 4 jam. Massa kelapa Sampel C setelah pengeringan sebesar 213,2 gr dengan proses pemanasan awal yang sama dengan A dan B dan juga dengan temperatur pemanasan akhir sebesar $80^{\circ} \mathrm{C}$ dan waktu pengeringan yang dibutuhkan selama 3 jam. massa kelapa Sampel D setelah pengeringan sebesar 213 gr dengan temperatur $55^{\circ} \mathrm{C}-80^{\circ} \mathrm{C}$ dan waktu pengeringan yang dibutuhkan selama 10 jam.

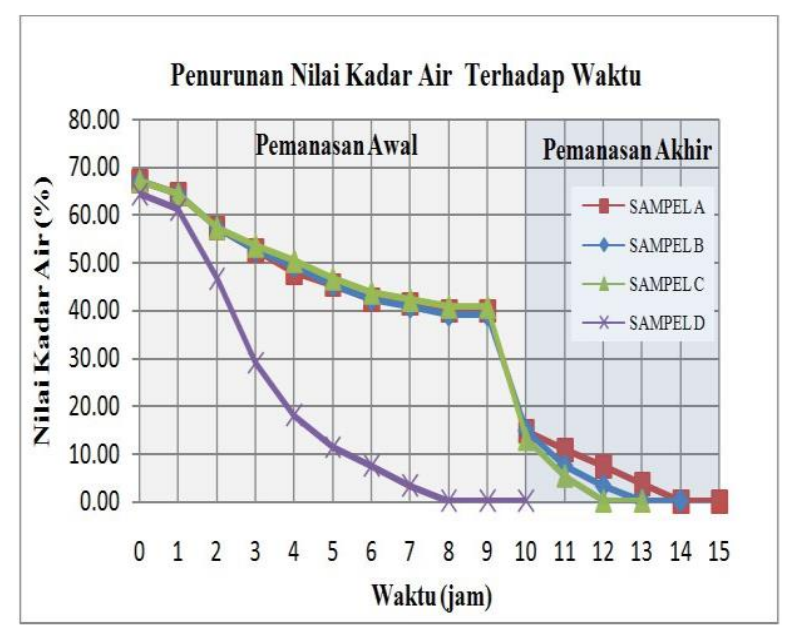

Gambar 4. Grafik perbandingan nilai kadar air sampel kelapa

Gambar 4 menjelaskan tentang perbandingan kadar air terhadap waktu. Pada Sampel A kadar air akhir yang diperoleh dari hasil proses pengeringan sebesar $0,14 \%$ dan waktu yang dibutuhkan untuk 
mencapai kadar air tersebut selama pemanasan awal 9 jam dan pemanasan akhir 5 jam. Sampel B diperoleh kadar air sebesar 0,19\% dan waktu yang dibutuhkan untuk pemanasan awal 9 jam dan pemanasan akhir 4 jam. Sampel C diperoleh kadar air sebesar 0,28 \% dan waktu yang dibutuhkan untuk pemanasan awal 9 jam dan pemanasan akhir 3 jam. Sampel D diperoleh kadar air sebesar 0,19\% dan waktu yang dibutuhkan $10 \mathrm{jam}$. Dari hasil pembahasan menunjukan bahwa sampel A memiliki kadar air yang lebih kecil disbanding sampel lain, namun tidak efektif karena waktu yang dibutuhkan untuk mencapai kadar air maks 0,2 \% (SNI,2008) lebih lama dibanding sampel lain.

\section{a. Hasil Pengolahan Minyak Kelapa Murni (Virgin Coconut Oil).}

Berdasarkan penelitian yang telah dilakukan, maka didapatkan hasil pengolahan VCO sebagai berikut

1. Hasil pengolahan VCO dengan menggunakan oven sebagai pemanas selama 9 jam pemanasan awal dan 5 jam pemanasan akhir (SAMPEL A) didapat VCO yang memiliki bau khas kelapa segar, tidak tengik, rasa normal khas minyak kelapa, tidak berwarna, memiliki kadar air 0,08 \% dan kadar asam lemak bebas 0,10\% (Hasil Pengujian Balai Pengujian dan Sertifikasi Mutu Barang(BPSMB)) memenuhi SNI VCO, 2008. Hasilnya seperti gambar 5 dibawah ini :

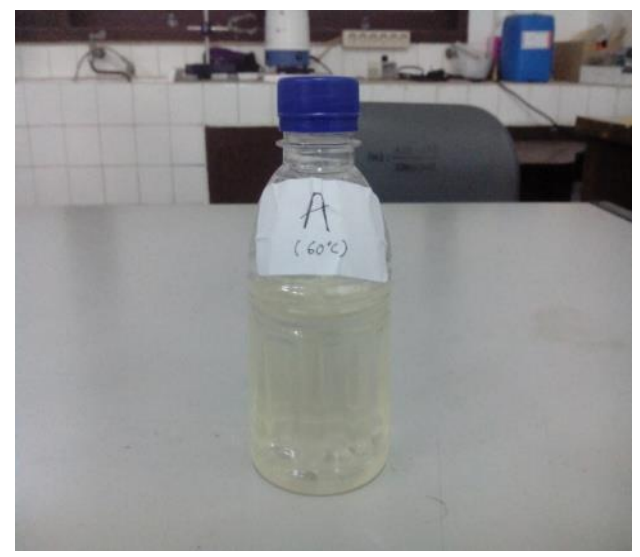

Gambar 5. VCO dengan temperatur pemanasan akhir60 ${ }^{\circ} \mathrm{C}$ (sampel A)

2. Hasil pengolahan VCO dengan menggunakan oven sebagai pemanas selama 9 jam pemanasan awal dan 4 jam pemanasan akhir (SAMPEL B) didapat VCO yang memiliki bau khas kelapa segar, tidak tengik, rasa normal khas minyak kelapa, tidak berwarna, memiliki kadar air 0,11\% dan kadar asam lemak bebas 0,15\% (Hasil Pengujian BPSMB) memenuhi SNI VCO, 2008. Hasilnya seperti gambar dibawah ini :

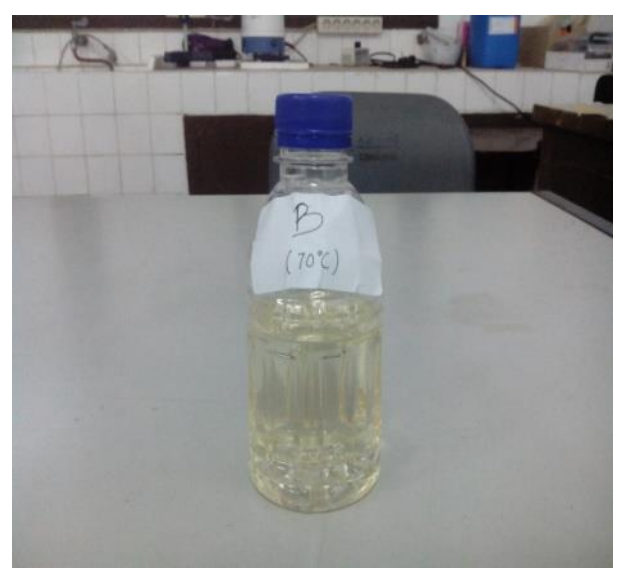

Gambar 6. VCO dengan temperatur pemanasan akhir $70^{\circ} \mathrm{C}$ (sampel B) 
4. Hasil pengolahan VCO dengan menggunakan oven sebagai pemanas selama 9 jam pemanasan awal dan 3 jam pemanasan akhir (SAMPEL C) didapat VCO yang memiliki bau khas kelapa segar, tidak tengik, rasa normal khas minyak kelapa, tidak berwarna, memiliki kadar air 0,20\% dan kadar asam lemak bebas 0,13 \% (Hasil Pengujian BPSMB) memenuhi SNI VCO, 2008. Hasilnya seperti gambar dibawah ini :

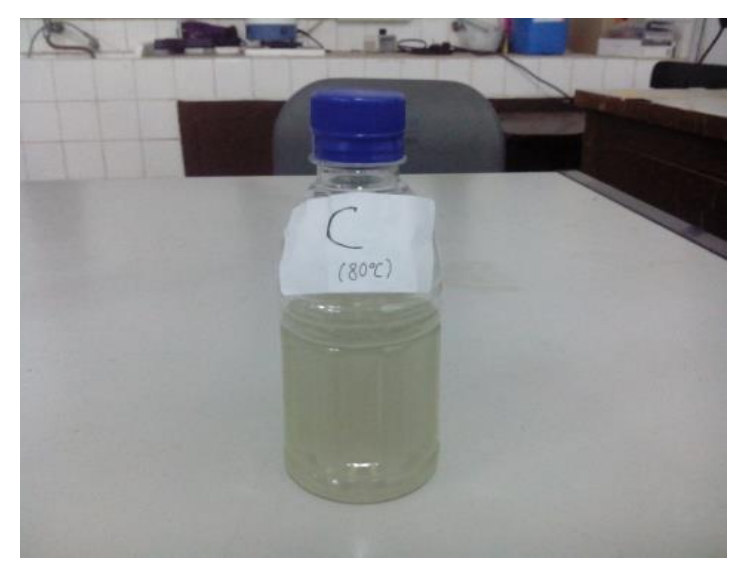

Gambar 7. VCO dengan temperatur pemanasan akhir $80^{\circ} \mathrm{C}$ (sampel C)

5. Hasil pengolahan VCO dengan menggunakan oven sebagai pemanas selama 10 jam (SAMPEL D) didapat VCO yang memiliki bau khas kelapa segar, tidak tengik, rasa normal khas minyak kelapa, tidak berwarna, memiliki kadar air 0,10 \% dan kadar asam lemak bebas 0,30 \% (Hasil Pengujian BPSMB) tidak memenuhi SNI VCO, 2008. Hasilnya seperti gambar dibawah ini :

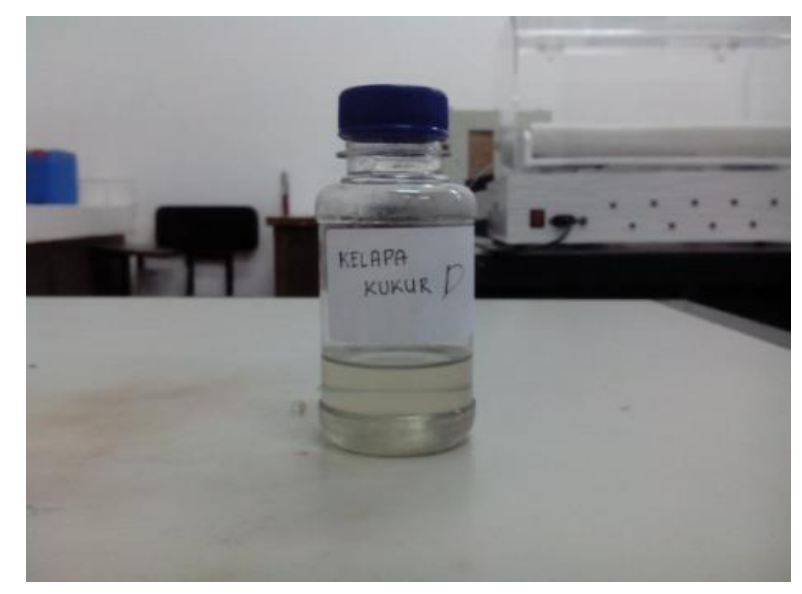

Gambar 8. VCO dengan temperatur pemanasan55-80 $\mathrm{C}$ (sampel D)

\section{Simpulan dan Saran}

Setelah dilakukan penelitian dan pembahasan data hasil pengujian, maka dapat diambil beberapa kesimpulan sebagai berikut : 1) Sampel A memiliki kadar air yang lebih kecil yakni sebesar 0,14\% pada kelapa yang dikeringkan dan 0,08\% pada minyak kelapa murni atau VCO, dibanding dengan sampel B, C dan D yakni sebesar 0,19\%,0,28\% dan 0,19\% pada kelapa yang dikeringkan dan 0,11\%,0,20\% dan 0,10\% pada VCO yang dihasilkan. Namun tidak efektif karena waktu yang dibutuhkan untuk mencapai kadar air maks 0,2\% (SNI VCO,2008) lebih lama sebesar 14 jam sedangakan sampel B,C dan D hanya membutuhkan 
waktu 13 jam, 12 jam dan 10 jam. 2) Sampel A memiliki kadar asam lemak bebas yang paling rendah yakni $0,10 \%$ dibanding dengan sampel B, C dan D yakni sebesar 0,15\%,013\% dan 0,30\%. Sampel D tidak memenuhi standart mutu (SNI VCO, 2008) dikarenakan kadar asam lemaknya melebihi 0,2\%. 3) Hasil penelitian menunjukan bahwa temperatur dan luas penampang bahan yang dikeringkan mempengaruhi kualitas produk dan lamanya pengeringan.

Penelitian ini masih tahap awal dan perlu dikembangkan lebih lanjut sistem pengolahan minyak kelapa murni dengan metode lainnya.

\section{Daftar Rujukan}

Dinas Perkebunan, 2012. Statistik Perkebunan Rakyat. Nanggroe Aceh Darussalam, Banda Aceh.

Handayani, S, 2007, Teknologi pengeringan awal pada proses pengolahan kopra menggunakanplate oven, Skripsi Teknik Pertanian Unsyiah.

Ketaren, 1986. Minyak dan Lemak Pangan. U.I press. Jakarta.

Palungkun, R, 1992. Aneka Produk Olahan Kelapa. Penebar Swadaya, Jakarta.

Syuhada, A. 2007. Oven pengering awal kelapa untuk bahan baku kopra,Lab. Rekayasa Thermal, Teknik Mesin Unsyiah.

Syuhada, A. 2011. Pemanasan awal kelapa batok untuk pengolahan kopra,Lab. Rekayasa Thermal, Teknik Mesin Unsyiah.

Taib, et, al, 1988. Operasi Pengeringan pada pengolahan Hasil Pertanian. PT. Mediyatama Sarana Pererkasa, Jakarta

Winarno, F.G., 1993. Pengantar Teknologi Bahan Pangan. PT. Gramedia, Jakarta 